БЕЗУСИЙ В.В.

\title{
СПЕЦИФІКА СОЦІАЛЬНОГО ЗАХИСТУ ДЕРЖАВНИХ СЛУЖБОВЦІВ В АВСТРІЇ
}

У статті проаналізовано сутність соціального захисту державних службовців в Австрії. Наведено положення законодавства вказаної країни. Визначено перелік особливостей соціального захисту державних службовців в Австрії. Розкрито зміст кожного з них. 3'ясовано, що у Німеччині запроваджена сімейна доплата, розміри якої державним службовцям Німеччини залежать від групи оплати праці та рівня сімейного стану. Загалом виділяють два рівні доплати, що залежать від сімейного стану державного службовця. До першого рівня належать: одружені службовці, судді та солдати; овдовілі службовці, судді та солдати; розлучені особи, які мають зобов'язання перед колишнім чоловіком чи дружиною щодо утримання; службовці, судді та солдати, які проживають разом з іншими особами і мають перед ними законодавчо зумовлені чи морального характеру зобов'язання щодо надання допомоги. До другого ступеня належать державні службовці, судді, солдати, які підпадають під дію закону про виплату грошей дітям. Подальші ступені залежать від кількості дітей у сім'ї. Сімейна доплата державним службовцям Німеччини надається, якщо сім'я має більш як одну дитину, а з урахуванням другої та кожної наступної дитини - сімейна доплата збільшується. Наголошено, що місячна оплата праці державного службовця Австрії складається із фіксованого посадового окладу і можливих надбавок: за вислугу років; за службову, функціональну, управлінську служби; за застосування, обслуговування виконавчої служби, військової служби; вихователю на дітей, у зв'язку з підвищенням цін. Зроблено висновок, що соціальний захист державних службовців Австрії має наступні особливості: широка диференційованість (розмір окладу визначається за одним із 19 тарифів та залежить не лише від займаної посади, але і від стажу та результатів виконання службових обов'язків); пожиттєва направленість (соціальний захист характеризується стимулюванням державних службовців до виконання своїх обов'язків протягом максимально довгого строку, зокрема, впровадженням доплат за 25 та 40 річну роботу у розмірі 200 та 400 відсотків від місячного окладу.

Ключові слова: сочіальний захист, державні службовиі, сочіальне законодавство, сочіальне забезпечення, державна служба.

In the article the essence of social protection of civil servants in Austria is analyzed. The provisions of the legislation of the specified country are resulted. The list of features of social protection of civil servants in Austria is defined. The content of each of them is revealed. It has been found that a family supplement has been introduced in Germany, the amount of which for German civil servants depends on the pay group and the level of marital status. In general, there are two levels of surcharges, depending on the marital status of the civil servant. The first level includes: married employees, judges and sol-

( БЕЗУСИЙ В.В. - кандидат юридичних наук, доцент, професор кафедри правового забезпечення господарської діяльності факультету № 6 (Харківський національний університет внутрішніх справ) 
diers; widowed officials, judges and soldiers; divorced persons who have a maintenance
obligation to their ex-spouse; civil servants, judges and soldiers who live with other
persons and have legal or moral obligations to provide assistance. The second degree
includes civil servants, judges, and soldiers who fall under the law on the payment of
money to children. Further stages depend on the number of children in the family. Family
allowances are provided to German civil servants if the family has more than one child,
and the family allowance is increased for the second and each subsequent child. It is
emphasized that the monthly salary of an Austrian civil servant consists of a fixed salary
and possible allowances: for years of service; office; functional; management service;
application, maintenance, executive service; military service; educator, for children, due
to rising prices. It is concluded that the social protection of Austrian civil servants has
the following features: wide differentiation (salary is determined by one of the 19 rates,
and depends not only on the position, but also on the length of service and performance
of duties); lifelong orientation (social protection is characterized by encouraging civil
servants to perform their duties for the longest possible period, including the introduction
of surcharges for 25 and 40 years of work in the amount of 200 and 400 percent of the
monthly salary.

Key words: social protection, civil servants, social legislation, social security, civil service.

Вступ. Дослідження відповідного зарубіжного досвіду дозволяє впроваджувати в національну систему соціального захисту державних службовців ефективні та перевірені елементи, які дозволяють найбільш доцільний вектор розвитку даного напряму забезпечення державної служби. При цьому саме постійна модернізація державної служби та усіх ії складових частин дозволяє забезпечити ефективне функціонування державних інституцій з метою належного адміністрування суспільних відносин.

Відзначимо, що важливим $є$ виокремлення необхідної та належної вибірки країн, дослідження яких дозволять сформувати релевантні результати, які дозволять виокремити лише ті новели в правовому регулюванні, які дозволять створити дійсно ефективні способи та засоби соціального захисту державних службовців.

Стан дослідження. Дослідженням зарубіжного досвіду, в тому числі соціального захисту державних службовців, займались такі учені, як В.А. Багрій, В.Д. Бакуменко, К.К. Баранцева, I.С. Бондар, І.А. Василенко, А.С. Головачова, В.Г. Горник, І.А. Грицяк, І.О. Драган, С.Е. Зелінський, М.І. Іншин, М.І. Лахижа, І.П. Лопушинський, Ю.Ю. Кізілов, А.В. Кірмач, Т.І. Марішенкова, Н.М. Мельтюхова, Н.М. Неумивайченко, В.В. Полтавский, С.І. Пономаренко, Л.В. Сергієнко, Є.С. Чорноног, Л.А. Шереметьєва, В.В. Шпачук.

Постановка завдання. Метою статті є дослідження специфіки соціального захисту державних службовців в Австрії.

Результати дослідження. С.Е. Зелінський відзначає, що в процесі історичних подій в кожному суспільстві формувалося власне розуміння функцій держави залежно від соціальних характеристик, національної філософії, менталітету, ідеології, віросповідання і традицій. Сьогодні в організаційно-правовій структурі державної служби можна виділити такі моделі: 1) романо-германська (кар'єрна); 2) англосаксонська (позиційна); 3) трудова; 4) ісламська; 5) східно-азіатська (елітна); 6) корпоративна; 7) менеджериальна (постбюрократична) [1, с. 38]. Вважаємо, що найбільш доцільним є вивчення досвіду країн, які за організаційно-правовою структурою державної служби подібні до України, оскільки це надасть найбільш релевантні результати дослідження з метою їх подальшого ефективного впровадження. Так, основною рисою кар'єрної моделі, яку впроваджено у Австрії, є орієнтація на закритість кар'єри та нематеріальні пільги і гарантії на державній службі (соціальний захист державних службовців, пенсійні гарантії, стабільність статусу). Враховуючи подібність орієнтирів забезпечення державної служби, вважаємо, що саме досвід країн (зокрема Німеччини - саме вона є додатковим складником для запозичення досвіду Австріі) кар'єрної моделі щодо забезпечення соціального захисту державних службовців необхідно дослідити.

Основним нормативним актом, що регулює діяльність німецьких чиновників, $є$ Федеральний закон про чиновника 1971 року. Цей закон з погляду мотивації орієнтований на матеріальне стимулювання. Матеріальне стимулювання німецьких чиновників складається із основного окладу, територіальної надбавки, надбавки на дітей, за вислугу років, за звання [2, с. 130]. При цьому 
визначальним, на нашу думку, є те, що конституційною основою оплати праці службовців ФРН $\epsilon$ принцип «утримання» - один з основних принципів статусу чиновника (Sorgepflicht). Держава має дбати про благо службовця і благо його сім’ї, надавати допомогу і захищати його в період трудової діяльності. Фактично держава платить не за працю службовця, вона оплачує його функцію. Оплата праці має бути співмірною і відповідати займаній посаді. Вона має забезпечити працівникові можливість повністю присвятити себе своїй роботі, оскільки лише фінансово незалежний службовець може самовіддано працювати на державу [3, с. 52]. Фактично цим принципом запроваджено стандарт забезпечення державного службовця, що впроваджує одночасне ефективне здійснення своїх обов'язків та відсутність необхідності у здійсненні корупційних діянь державним службовцем.

Так, зокрема, рівень оплати праці федеральних державних службовців Німеччини регулюється Федеральним законом про заробітну плату від 23 травня 1975 р. зі змінами і доповненнями [4]. Цей закон регулює оплату праці федеральних державних службовців за винятком почесних чиновників, федеральних суддів, а також народних засідателів, солдатів-контрактників та солдатів строкової служби. Зауважимо, що до складу німецьких державних службовців належать: чиновники державного апарату; судді; вчителі; викладачі вищих навчальних закладів; військовослужбовці; поліція; пожежна служба; працівники пошти, залізниці, державних банків; працівники медичних установ [5]. Для оплати праці в кожній із земель прийнятий власний земельний закон, який не повинен суперечити федеральному [4]. Заробітна плата складається з таких виплат: базового окладу; додаткових виплат для викладачів, що мають повну зайнятість як керівники чи члени керівних органів у вищій школі; сімейної доплати; надбавки; відшкодування; плати за перебування за кордоном. Також до платні передбачені такі подальші доплати: доплата за стаж, річна спеціальна виплата, доплата з фонду економії заробітної плати [4]. Загальний розмір премій і надбавок за ефективність праці, що призначається роботодавцем протягом календарного року, не повинен перевищувати $15 \%$ від загального окладу службовців. Премії та надбавки за ефективність праці не враховуються під час визначення розміру пенсії службовців.

Державним службовцям гарантуються соціальні виплати, що включають пенсійне забезпечення, матеріальну допомогу, забезпечення сім'ї після смерті державного службовця, компенсації при нещасних і в інших особливих випадках. Їм також гарантується оплата витрат у разі зміни місця проживання в зв'язку зі службовою необхідністю [6, с. 74]. Таким чином, ми можемо спостерігати досить широкий спектр можливих надбавок та виплат, який впроваджено з метою соціального захисту державних службовців, при цьому відповідні виплати передбачені у зв'язку із досить широким переліком можливих юридичних фактів, пов'язаних із різними життєвими обставинами. Загалом з метою впровадження подібного регулювання в Україні рівень соціального захисту безперечно підвищиться, однак на цьому етапі розвитку економіки України подібні витрати, на нашу думку, є недоцільними.

Водночас досить цікавою з погляду науки є запроваджена у Німеччині сімейна доплата, розміри якої державним службовцям Німеччини також залежать від групи оплати праці та рівня сімейного стану [4]. Загалом виділяють два рівні доплати, що залежать від сімейного стану державного службовця. До першого рівня належать: одружені службовці, судді та солдати; овдовілі службовці, судді та солдати; розлучені особи, які мають зобов'язання перед колишнім чоловіком чи дружиною щодо утримання; службовці, судді та солдати, які проживають разом з іншими особами і мають перед ними законодавчо зумовлені чи морального характеру зобов'язання щодо надання допомоги. До другого ступеня належать державні службовці, судді, солдати, які підпадають під дію закону про виплату грошей дітям. Подальші ступені залежать від кількості дітей у сім'ї. Сімейна доплата державним службовцям Німеччини надається, якщо сім'я має більш як одну дитину, а з народженням другої та кожної наступної дитини сімейна доплата збільшується.

Враховуючи вищенаведене, можемо відзначити, що соціальний захист державних службовців у Німеччині характеризується такими особливостями:

1) Фінансово-незалежний характер (тобто держава намагається здійснити достатній рівень фінансування державного службовця, який забезпечить відсутність у нього необхідності у додатковому заробітку).

2) Співмірність (тобто рівень соціального захисту, зокрема фінансового забезпечення, напряму залежить від займаної посади).

3) Багатовекторність (соціальний захист державних службовців у Німеччині характеризується значною кількістю різноманітних за своєю підставою виплат). 
Закон про оплату праці Австрійської республіки виокремлює 10 тарифікаційних груп службовців: 1) службовці загального управління; 2) судді і державні адвокати; 3) викладачі університетів; 4) вчителі; шкільні і фахові інспектори та чиновники служби нагляду за школою; службовці виконавчої гілки влади та службовці охорони; 7) військові службовці: рядовий склад та професійні офіцери; 8) службовці пошти та зв'язку; 9) службовці лікувальних закладів та установ; 10) службовці адміністрації управління пошти та зв'язку [7]. Сучасна система заробітної плати на публічній службі Австрії запроваджена реформою заробітної плати 1994 р. Згідно з законом про заробітну плату кожен державний службовець належить до певної групи оплати праці [7]. Наразі існує 19 рівнів тарифікації заробітної плати. Рівень заробітної плати прив'язаний також до службового просування, яке залежить від стажу, робочого місця (посади) та результатів праці.

Місячна оплата праці державного службовця Австрії складається із фіксованого посадового окладу і можливих надбавок: за вислугу років; за службову, функціональну, управлінську служби; за застосування та обслуговування виконавчої служби; за військову службу; вихователю на дітей у зв'язку з підвищенням цін. Місячна заробітна плата виплачується першого числа кожного місяця. Якщо перше число припадає на неробочий день, то виплата здійснюється заздалегідь у попередній робочий день. Окрім місячних виплат, передбачено також особливий щоквартальний платіж у розмірі 50\% місячного окладу. Термінами виплати особливого щоквартального платежу є: за перший квартал - 1 березня, другий - 1 червня, третій - 1 вересня, четвертий - 1 грудня. Виплачуються також кошти за сумлінну службу службовцям, які пропрацювали на державній службі 25 чи 40 років. Розмір виплати при досягненні 25-річного перебування на службі становить $200 \%$, а 40 -річного - $400 \%$ місячного окладу. Якщо службові відносини завершуються смертю службовця, то виплата здійснюється спадкоємцям покійного в розмірі $150 \%$ посадового окладу.

Відзначимо, що надбавки за стаж державної служби на цьому етапі передбачені українським законодавством. Зокрема, частиною 1 статті 52 Закону України «Про державну службу» визначено, що надбавка за вислугу років на державній службі встановлюється на рівні 3 відсотків посадового окладу державного службовця за кожний календарний рік стажу державної служби, але не більше 50 відсотків посадового окладу [8]. Водночас доцільним вважаємо введення саме премії за довготривале проходження державної служби, що повинно підняти рівень соціального захисту та мотивації державних службовців, які виконують свої обов'язки на благо держави протягом тривалого часу.

Для впровадження зазначеного преміювання пропонуємо частину 1 статті 52 Закону України «Про державну службу» доповнити абзацом 2 такого змісту: «Державним службовцям, строк служби яких становить 25 та 40 років, здійснюється одноразова виплата при досягненні 25-річного перебування на службі у розмірі $200 \%$, а 40-річного перебування на службі - $400 \%$ місячного окладу. Якщо службові відносини завершуються смертю службовця, то виплата здійснюється спадкоємцям покійного в розмірі 150\% посадового окладу».

Відповідна зміна дозволить підвищити престиж державної служби та впровадити додаткову мотивацію для державних службовців проходити службу протягом більш тривалого часу. Досить важливим є можливість отримання такої доплати спадкоємцями державного службовця, що підвищить рівень соціального захисту не лише самого державного службовця, але і членів його сім'ї.

Можливість отримання додаткових благ у довготривалій перспективі дозволить зменшити відтік цінних кадрів державної служби до приватного сектору, що матиме позитивний вплив на ефективність виконання державою взятих на себе обов'язків.

Висновки. 3 наведеного аналізу можна зробити висновок, що соціальний захист державних службовців Австрії має такі особливості:

1) широка диференційованість (розмір окладу визначається за одним із 19 тарифів та залежить не лише від займаної посади, але і від стажу та результатів виконання службових обов'язків);

2) пожиттєва направленість (соціальний захист характеризується стимулюванням державних службовців до виконання своїх обов'язків протягом максимально довгого строку, зокрема, впровадженням доплат за 25 та 40 річну роботу у розмірі 200 та 400 відсотків від місячного окладу.

\section{Список використаних джерел:}

1. Зелінський С.Е. Теоретико-методологічні засади комплексного оцінювання державних службовців : монографія. Київ : НАДУ, 2016. 296 с.

2. Василенко И.А. Административно-государственное управление в странах Запада: США, Великобритания, Франция, Германия. Москва : Логос, 2000. 
3. Лопушинський І.П. Публічна служба Німеччини: досвід для України. І.П. Лопушинський. Публічне управління: теорія та практика. 2011. № 4 (8). С. 48-54.

27.10.2019).

4. Bundesbeamtengesetz (BBG). URL: http://www.beamtengesetz.de. (дата звернення -

5. Beamten-Dienstgesetz. URL: https://www.ris.bka.gv.at/GeltendeFassung.wxe?Abfrage= Bundesnormen\&Gesetzesnummer=10008470.

6. Марішенкова Т. Державний службовець у Німеччині. Збірник тез Всеукраїнського студентського онлайн-форуму «Державний службовець закордоном: знімаємо маски», присвяченого 100-річчю державної служби в Україні. Житомир : ЖДТУ, 2018. С. 72-76.

7. Bundes-Vervassungsgesetz. URL: https://www.ris.bka.gv.at/GeltendeFassung.wxe?Abfrage= Bundesnormen\&Gesetzesnummer=10000138 (дата звернення -30.10 .2019 року).

8. Про державну службу. Закон України від 10.12 .2015 № 889-VIII. URL: https://zakon.rada.gov.ua/laws/show/889-19 (дата звернення: 28.10.2019).

УДК 349.2

DOI https://doi.org/10.32844/2618-1258.2019.6.9

БОНДАР В.I.

\section{ДО ПРОБЛЕМИ КОМПЛЕКТУВАННЯ СЛУЖБИ СУДОВОЇ ОХОРОНИ}

У статті на основі аналізу наукових поглядів вчених та норм чинного законодавства України обгрунтовано, що найбільш дієвим способом комплектування Служби судової охорони є здійснення конкурсного відбору на посаду. Визначено, що конкурс - це перш за все процедура, яка складається з чітко визначених дій, котрих обов'язково мають дотримуватись суб'єкти, уповноважені на проведення конкурсу. На цей час питання конкурсного відбору працівників Служби судової охорони регулюється «Порядком проведення конкурсу для призначення на посади співробітників Служби судової охорони», який було затверджено Рішенням Вищої ради правосуддя від 30 жовтня 2018 року № 3308/0/15-18, із змінами та доповненнями, які були внесені до нього у зв'язку із реформуванням Служби судової охорони. 3'ясовано, що необхідним комплектом документів від претендентів на зайняття вакантних посад є: 1) письмова заява про участь у конкурсі, у якій також зазначається надання згоди на проведення спеціальної перевірки стосовно неї відповідно до Закону України «Про запобігання корупції» і на обробку персональних даних відповідно до Закону України «Про захист персональних даних»; 2) копія паспорта громадянина України; 3) копії (копії) документа (документів) про освіту; 4) заповнена особова картка визначеного зразка, автобіографія, фотокартка розміром 30 х 40 мм; 5) декларація, визначена Законом України «Про запобігання корупції» (роздрукований примірник із сайту Національного агентства з питань запобігання корупції); 6) копія трудової книжки (за наявності), довідка Ф1 (для атестованих працівників) або копія послужного списку (для цивільних осіб); тощо. Наголошено, що формування кадрового резерву, беззаперечно, $є$ важливим аспектом комплектування Служби судової охорони, саме за його допомогою вбачається можливим: по-перше, створити сприятливі умови для кар'єрного зростання вже наявних службовців відомства, що своєю чергою $є$ важливим стимулом для працівників більш якісно виконувати свої посадові обов'язки; по-друге, забезпечити стабільність кадрів, уникнути так званої «кадрової кризи». Існування кадрового резерву дасть змогу подолати негативні аспекти плинності кадрів на керівних посадах державної служби, поступово та послідовно готувати високопрофесійних керівників і фахівців для

(C) БОНДАР B.I. - здобувач кафедри правового забезпечення господарської діяльності факультету № 6 (Харківський національний університет внутрішніх справ) 